\title{
The Strategic Evolution of Fashion Flagship Stores
}

\author{
Edoardo Sabbadin ${ }^{1} \&$ Simone Aiolfi ${ }^{2}$ \\ ${ }^{1}$ Professor of Marketing, Department of Economics, University of Parma, Italy \\ ${ }^{2}$ Adjunct Professor of Marketing, Department of Economics, University of Parma, Italy \\ Correspondence: Prof. Simone Aiolfi, Department of Economics, University of Parma, Via J.F. Kennedy 6 - \\ Parma - 43125, Italy. E-mail: simone.aiolfi@unipr.it
}

Received: May 14, 2019

doi:10.5539/ijbm.v14n9p123
Accepted: June 20, 2019

Online Published: August 5, 2019

URL: https://doi.org/10.5539/ijbm.v14n9p123

\begin{abstract}
About thirty-five years ago the trend of investing in flagship stores in the fashion and luxury sectors started, and has not stopped even since the last economic crisis. Recently, flagship stores have expanded into new sectors. There is an increased interest in flagship stores; but until now, they have received little attention in academic research. Published papers are mainly related to the fields of luxury shopping and internationalization studies.

Nowadays, the term "flagship store" is ambiguous; it has different meanings. A flagship brand store is, in general terms, the most important, expensive, and representative store of the brand. It has to show the full range of products and services offered. Usually it is the largest store, in the most prestigious location, and adopts original store design solutions; they offer new facilities, and a very high service level. Moreover, flagship designers are famous and prestigious architects; ("Signature" architects, or "Archistars") and the aim is to create iconic buildings.

The store design solutions are different from other mono-brand stores or franchisee outlets of the company.

Academic research until recent years has overlooked studying the trend of the main luxury and fashion international companies opening flagship stores; which are the most expensive type of retail stores to own, nevertheless a number of questions remain. The purposes of this paper are (1) to consider the evolution of the role of the main types of flagship stores, (2) to establish whether flagship stores constitute a marketing innovation, (3) to discuss factors pushing firms to develop flagship stores and finally, (4) to assess implications for management. In order to answer to our research questions, the study adopts a qualitative approach, in the belief that this type of research is consistent with the research questions. Particularly, we adopted two research methods: interviews and cases studies. We collected interviews with store designers and entrepreneurs. Finally, some information was also collected from secondary sources such as web sites or company news. Our study provides relevant information for marketing managers considering the cost of investing in flagship stores. Vertical branding and new flagship brand stores are becoming increasingly widespread among different firms and sectors, and are bringing to the forefront a requirement for new skills. Particularly in the store design phase, where firms need to be able to take part in constructive dialogue with a wide variety of professional profiles like architects, internal designers, and visual merchandisers. They need a new approach to decoding and displaying the primary values of a brand through innovative store design solutions and sales points, which should be inspired by the communication and entertainment industries. Flagship brand stores should be designed and run to be unique unrepeatable places, able to enhance brand image and provide animation and entertainment value to the brand. Furthermore, flagship store success depends on the firm's ability to integrate interdisciplinary issues and commercial and artistic-creative communication.
\end{abstract}

Keywords: flagship stores, retail marketing innovation, Luxury and fashion branding

\section{Objectives}

Nowadays, the term "flagship store" is ambiguous and it has different meanings. A flagship brand store is, in general, the most important, expensive, and representative store of the brand. It has to show the full range of products and services offered. Flagship stores are larger than single brand stores, usually on several floors and are located in important shopping locations. Flagship stores make a statement and demonstrate the strength of the brand with the aim of enhancing it. They offer new facilities and a very high service level. Moreover, flagship store designers are famous architects and the goal is to utilize "Signature" architects, or "Archistars" to create 
iconic buildings (Webb, 2009). The store design solutions are different from other mono-brand stores or franchisee outlets of the brand company.

They make the supply of goods into a spectacle, and by entertaining customers and providing a show of strength, flagship stores make shopping into a positive and unique experience. About 35 years ago the trend of investing in flagship stores in the fashion and luxury sectors started. This trend has continued even with the last economic crisis (after 2008). The literature on flagship brand stores is growing; but in different directions. One is internationalization. Some papers focused on luxury and fashion sectors analyzed flagship stores as an international market entry model (Moore, Doherty \& Doyle, 2010). Recently, flagship stores have expanded from fashion and luxury retailing into new sectors.

The management literature on innovation focuses on high-technology industries. Instead, innovation receives less attention in low technology industries, as retailing and service. Are flagship stores a marketing innovation? The answer is complex because a flagship store is a multidimensional concept: Is it a service innovation? Is it an innovation in service design? Is it an innovation in the brand communication? The flagship store is a real and physical incarnation of the brand. Flagship stores use location, store design, services, and facilities to build brand equity. Now is the strategy to open expensive flagship stores effective and efficient for brand power communication? The purposes of this paper is to study the evolution of the marketing roles of flagship stores, to identify the main types of flagship stores in order to establish whether flagship stores constitute a marketing innovation, to identify the main factors pushing firms to develop flagship stores. Furthermore, interesting implications for managers and retail management could emerge.

According to the proposed theoretical background, we have identified the following research questions:

Q1: What is a flagship store?

Q2: What are the strategic marketing functions of a flagship brand store?

Q3: Are flagship stores design different from other mono-brand stores?

Q4: What are the specific characteristics of flagship stores?

Q5: What is the source of the power of design in the flagship store environment?

Q6: What is their marketing role in building brand equity?

Q7: What are the main links in the brand equity building process?

Q8: What leads firms to integrate downstream and develop through flagship store?

Q9: Are flagship store the new main competitors of independent retailers or chain stores?

Q10: What are the competitive advantages of the flagship marketing strategy?

Q11: What are the main managerial implications?

The purposes of this paper are:

1. To consider the evolution of the role of the main types of flagship stores;

2. To establish whether flagship stores constitute a marketing innovation;

3. To discuss factors pushing firms to develop flagship stores;

4. To assess implications for management.

\section{Methodology}

In order to answer to our research questions, the study adopts a qualitative approach, because we believe that it is the one most consistent with the research questions. Particularly, we adopted two qualitative research methods used in previous studies: interviews and cases studies. We collected interviews with store designers and entrepreneurs of the fashion and luxury sector. Some information was also collected from secondary sources such as companies' official web sites or company recent news.

The research was carried out as follows:

1. Flagship and temporary stores were the primary sources of information. 50 stores were studied with field analysis. Data was collected and classified for multidisciplinary case studies.

2. 85 firms with downstream integration in single brand stores and franchising were invited to complete a questionnaire (20 firms from the fashion sector).

3. We started the research first featuring interviews with store designers that are constantly in touch with the 
fashion and luxury leading groups. Then we analyzed case studies such as Freitag in Zurich, which opened in 2006, and the Gucci flagship store in the Brera district of Milan, which opened in 2013.

\section{Findings}

What are the main characteristics of flagship stores? What are the main differences between flagship stores and mono-brand stores? (see Table 1)

Kozinets et al. (2002) "identify several types of brand-related stores. Flagship brand stores can be distinguished by three characteristics. First, they carry a single (usually established) brand of product. Second, that brand's manufacturer owns them. Finally, they are operated, at least in part, with the intention of building or reinforcing the image of the brand rather than operating to sell product at a profit. Flagship brand stores can be exclusive outlets for a manufacturer's brand.

Kozinets et al. (2002) also introduced the concept of themed entertainment brand stores, which are focused primarily on selling services rather than selling products (e.g. Planet Hollywood, The Hard Rock Cafe', Rainforest Cafe', Steven Spielberg's Dive! restaurants, and the Fashion Cafe').

For Kozinets et al. (2002), flagship stores are used to build new relationships with consumers. Kozinets et al. (2002) underlined that the objective of flagship stores is "to take the branding concept to an extreme level". It is a long-term marketing communication investment. "Budgets for flagship brand stores should be viewed as part of a long-term brand building strategy and as an entry into a different type of business (i.e., quasi-entertainment)" (Kozinets et al., 2002). Kozinets et al. (2002) theorized that flagship stores emerged to offer entertainment and brand experience in an environment controlled by manufacturer".

Webb (2002) identified a number of fundamental characteristics common to flagship stores: "larger format stores, major city/high footfall store locations; architectural "iconicism" manifest in a high investment in building, interiors and fittings".

Also Kent (2009) underlined the importance of location in major cities, and in specific areas: the main shopping streets. Nobbs et al. (2012) identified the key characteristics of the flagship concept, and identified new trends of this dynamic and expensive store format. They identify essential elements of the format: scale and size, exclusivity and uniqueness, and the objective to offer the customer a justification for their visit.

Kozinets et al. (2002) argued that flagship stores will never become universal, because they are likely to be effective only for strong brand appeal in luxury and fashion sectors.

Table 1. Definitions of the flagship store format

\begin{tabular}{|c|c|}
\hline Definitions & Authors \\
\hline $\begin{array}{l}\text { [.. .] "the major shop or outlet in a chain, usually located in capital cities, which is larger than } \\
\text { major outlets and carries a wider range of merchandise. It carries the flag for the chain and } \\
\text { maybe the trial ground for new ideas. The store is usually furbished to a higher standard than } \\
\text { the others and may have its own unique identity in the chain". }\end{array}$ & Baron et al. (1991, p. 82) \\
\hline $\begin{array}{l}\text { "They carry a single brand, the brand manufacturer owns them, they are operated with the } \\
\text { intention of building the brand rather than operating to sell product" }\end{array}$ & Kozinets et al. $(2002$, p. 17$)$ \\
\hline $\begin{array}{l}\text { "a flagship store can be defined as the large or dominant store in a prime location, which } \\
\text { often acts as a brand monument, ultimately creating a } 3 \mathrm{D} \text { production of all that their brand is } \\
\text { about ... these places are about selling a lifestyle and giving customers something to aspire } \\
\text { to" }\end{array}$ & Tucker (2003:28-30) in Webb (2009) \\
\hline $\begin{array}{l}\text { "Allows the brand to re-enforce it's image communication through establishing a physical } \\
\text { presence in a prestige shopping location and to influence the experience at the point of sale" }\end{array}$ & Jackson $(2004$, p. 177) \\
\hline $\begin{array}{l}\text { "The pinnacle in retail chain, usually large and located in a prestigious, high foot-traffic } \\
\text { location, with a full range of merchandise but an emphasis on the more expensive high quality } \\
\text { and high fashion lines" }\end{array}$ & Varley $(2007$, p. 176) \\
\hline $\begin{array}{l}\text { "A translation of the marketing strategy into a } 360 \text { degree experience of consumption, and is } \\
\text { increasingly becoming the company's prime mass medium" }\end{array}$ & Moore (2007, p. 25) \\
\hline $\begin{array}{l}\text { "They are distinguishable from the rest of the retail network due to their scale, design, } \\
\text { location and set-up and operating costs. Their decadent size provides a positive signal with } \\
\text { regard to the identity and prestige of the luxury brand" }\end{array}$ & Moore et al. (2010, p. 156) \\
\hline
\end{tabular}

Source: our elaboration. 
Table 2. The Dimensions of a Flagship Store and Mono-Brand Store

\begin{tabular}{|c|c|c|}
\hline The Dimension & Flagship Stores & Mono-Brand Outlets \\
\hline Size & The largest store of a company & Medium size \\
\hline Target & Stakeholder & Brand loyal consumers \\
\hline Location & $\begin{array}{l}\text { Major city/high foot-traffic store locations. } \\
\text { The most prestigious and expensive } \\
\text { locations. } \\
\text { "Brand stores aggregate into the chose } \\
\text { neighborhood, mutually reinforcing each } \\
\text { other's values . . . . Areas like Madison } \\
\text { Avenue in New York, the Ginza in Tokyo, } \\
\text { Bond Street in London, the Champs-Elysée } \\
\text { in Paris, Rodeo Drive in Los Angeles are } \\
\text { solely devoted to shopping as a global urban } \\
\text { city" (Koolhaas et.al. 2001: 166) }\end{array}$ & $\begin{array}{l}\text { Less expensive location and shopping mall } \\
\text { or shopping center. }\end{array}$ \\
\hline Store designer & $\begin{array}{l}\text { The designer is a very famous and } \\
\text { prestigious independent architect, an } \\
\text { "Archistar" and the aim is to create an iconic } \\
\text { building (Webb, 2013) }\end{array}$ & $\begin{array}{l}\text { Store design specialized partner, in most of } \\
\text { the cases the design team is inside the } \\
\text { organization. }\end{array}$ \\
\hline Service & High level of service and new facilities & Good level of service \\
\hline
\end{tabular}

Source: our findings.

In our study, we have identified the following classification system for the flagship stores:

1. Epicenters

2. Headquarter flagship stores

3. Media flagship stores

4. Mega-flagship stores

5. Flagship stores with services and facilities

Flagship stores are five to eight times larger than the average store of the same brand, usually on several floors and are located in important shopping locations (see Table 2). Flagship stores make a statement and demonstrate the strength of the brand with the aim of enhancing it. By occupying landmark buildings, they extend the brand into different areas of retail by appropriating the area and the local architecture in order to impress target customers. They make the supply of goods into a spectacle, and through entertaining customers and a show of strength make shopping into a positive and unique experience. They are located in prestigious shopping areas and streets and have high value as communication in terms of the flow of pedestrians and the symbolic importance of the area. Generally, the owner is the manufacturer and not a retailer.

For Kent and Brown (2009), the flagship is a new approach in strategic marketing and identifies three main flagship store characteristics: entertainment, service and brand experience.

Marketing literature has not paid due attention to semiotic interpretation of flagship brand stores. The increasing importance of intangible attributes has pushed the brand to a new communicative use of stores. For Semprini (2003), the brand evokes a possible world and tells stories, as if it was a work of literature, theatre, film.

Louis Vuitton, e.g., is a brand that has managed to propose a possible world, starting from the imaginary of the trip, the quality of craftsmanship, as well as innovation (Semprini, 2003). The possible worlds evoked by the brand are the result of an even balance between fiction, fantasy, and possibility of identification and projection. Particularly in the luxury fashion sector, the idea that outlets' selling different brands was less able to support a strong brand image started to gain currency.

The increasing importance given to non-tangible aspects of brand underpinned a surge of interest in single brand outlets. The marketing approach and traditional media have lost credibility in the process of construction of the world of the brand. New flagship brand stores, on the other hand, are a container for the value system carried by the brand whereby the consumer can experience the brand in direct contact through several senses by visiting the "possible world". Flagship brand stores have become the incarnation of brand image, and they are taken over by 
the "world of the brand", and become a concrete symbol.

What leads firms to integrate downstream and develop through flagship store? The first reason is connected to the need to communicate the value of the brand in order to improve brand communication. The second reason is the need to deal with new customer segments. The third is the desire for a direct relationship with the customer base. Furthermore, other interesting reasons are connected to the desire of providing emotional stimulation and the use of the sales point for marketing research. Therefore, downstream integration will require new skills: single brand flagship stores make necessary new and constructive dialogue with architects, internal designers, visual merchandisers, retailer and store managers. This involves a new interdisciplinary approach. The use of the arts, entertainment, and shopping as tools in urban regeneration is now a new trend which can contribute to the renewal of a neighborhood or of a city.

We started the research first featuring interviews with store designers that are in constant contact with the fashion and luxury leading groups. Then we did case studies such as the new Gucci flagship store in the Brera district of Milan, which opened in 2013, Freitag in Zurich, which opened in 2006, and 10 Corso Como also in the Brera district of Milan. Tiziano Vudafieri, a very famous architect and store designer, thinks that over the past few years the role of the main flagship stores has changed: while maintaining an important communicative role, they continue to keep a symbolic role, a true and live representation of the "strength" of the brand. They are a sure way to create a real world experience of the brand. However, from an accounting point of view, the flagship stores were a cost center, and now they are gradually becoming a profit center. After the 2008 crisis, the owners of the flagship stores have started to adopt solutions to increase flagship store turnover.

The new flagship store strategies go in two different directions. The first one includes lower priced items in the product assortment; the second one includes limited edition products specifically designed for the flagship store.

Another innovative strategy is to target a specific segment of the market- the new kind of tourist with a particular interest in luxury shopping.

We have investigated the case of the Brera District in Milan, Italy. In the review of the literature we found that flagship stores have the most prestigious and expensive locations. Now, the case of the shopping district of "Brera-Corso Garibaldi-Corso Como" in Milan highlights the fact that an area can be revitalized and redeveloped by a new flagship store location, as the new Gucci men's flagship store opened in 2013 and 10 Corso Como located at the opposite end of the Shopping district. Also in Paris the new flagship stores are not located in Champs-Elysée, but in new areas, and in buildings with a history and a meaning. The same trend can be found in New York in the Meatpacking district.

To conclude our findings demonstrate that the strategic challenge of flagship stores beyond 2008 were to reduce losses and gain store profit while maintaining their traditional role to build brand image, to increase brand awareness, and to provide brand experience. Furthermore, in the review of the literature, we found that flagship stores have the most prestigious and expensive locations (like Madison Avenue in New York, the Ginza in Tokyo, Bond Street in London, the Champs-Elysée in Paris, Rodeo Drive in Los Angeles). However, nowadays there are some innovative cases, in which new flagship store locations could revitalize and redevelop a neighborhood. Therefore, the new role is the opposite of what the literature underlined. Furthermore, a brand flagship store is a marketing innovation because, for the first time, the store itself is used like a media and an emotional tool. Flagship stores themselves are a marketing innovation aimed to open new markets abroad, better addressing new customer needs.

\section{Practical Implications}

What are the competitive advantages of the flagship marketing strategy? What are the main managerial implications?

The trend towards the increase of flagship brand stores has an important managerial implication. Manufacturing firms, which follow this strategy, need to have the capacity to manage an organizational change and find solutions to new management and development problems, which until today have usually been the territory of retail and service firms.

Kozinets et al. (2002) e.g. found that "For manufacturers, the strategic option to open a themed flagship brand store is a complex and challenging one. Major themed flagship brand stores are expensive to develop and maintain, and complicated to run. They require manufacturers to enter not only the retail business, but also the entertainment business. They require new sets of skills in merchandising, technology and in human resource recruitment and training. Most of the literature is focused on management implications; however, the most important and complex phase is designing a new flagship store concept. The question is how to communicate the 
future vision of brand image with a new location, building, physical space, color, music, furniture, employees, and a new mix of services.

How is a new flagship brand store designed? The development of an original flagship brand store design requires innovative input into services and parallel and consistent segmentation. The criteria for segmentation should enhance the image of the new store format. Clear and consistent identity is pivotal in communication. To design a new flagship brand stores requires new skills: a new and constructive dialogue with widely varying professional profiles: architects, internal designers, visual merchandisers, and retail and store managers. This involves a new interdisciplinary approach to decoding and enhancing primary brand values drawing on the world of communication studies and entertainment. In today's world, visual identity in form and content needs to be defined through innovation in sales outlets, but it is overlooked that this evolution requires new skills.

Our interviews with store designers enabled us to identify three main phases in developing a new brand flagship store:

1. Selection of architect or design studio: in most cases the architect/store designer is chosen directly by the entrepreneur and/or founder and senior management levels (CEO or GM), never by lower management levels. The famous architect Rem Koolhaas designed the New York Prada Epicenter in 2001, and the Los Angeles Prada Epicenter (2.200 sq. m), which opened in 2004. Architects Herzog \& de Meuron designed the second Prada Epicenter, which opened in 2003 in Tokyo. Renzo Piano designed the main flagship Hermès store in Tokyo in 2001. Japanese architect Jun Aoki designed the Louis Vuitton flagship store in Tokyo. One of the most original projects is the Marni flagship store designed by Future System Team. The architect/store designer is chosen according to conceptual and artistic agreement with the entrepreneur and/or founder and senior management. Some young companies select architects/store designers by inviting studios to tender.

2. Formulation of clear design brief: after the architect/store designer option, the company flagship project leader writes the brief. The architect or store design studio needs to have all the information necessary to design a new flagship store, which needs to be clearly structured relating to brand history as well as the directions of future development of the brand. However, the problem is to communicate the future development of brand identity and company vision of the business. Our interviews reveled, moreover, that in recent years the job of the store designer has taken on a big component of communication. One of the challenges of planning retail design of new stores and brand space has become the ability to increase the component of real brand values. The architecture and design is used to communicate the "possible world" of the brand.

3. Preliminary plan for design of concept store: we think that before to design a new flagship brand store concept, the following aspects need to be analyzed:

- Competitor solutions. Examining direct competitor solutions in service design sheds light on current trends and provides inspiration.

- Display requirements in terms of range, category, product lines, number of collections per year, services, etc.

- Demand for service design can be assessed through focus group studies, with the aim of finding out requirements for display and services of the main targets and responses to ideas for new criteria for bunching displays. Empirical experience shows that focus groups are unlikely to come up with original innovative solutions but are very helpful in identifying constraints that need to be placed on the architect's freedom in design.

- $\quad$ Store employee's requirements. The ergonomic requirements of sales people with direct customer contact can be ascertained through meetings with most active store managers.

Our study provides relevant information for marketing planners considering the cost of investing in flagship stores. Vertical branding and new flagship brand stores are becoming increasingly widespread among different firms and sectors, and are bringing to the forefront a requirement for new skills. In the store design phase, firms need to be able to take part in constructive dialogue with a wide variety of professional profiles like architects, internal designers, and visual merchandisers. They need a new approach to decoding and displaying the primary values of a brand through innovative store design solutions and sales points, which should be inspired by the communication and entertainment industries.

Flagship brand stores should be designed and run to be unique unrepeatable places. They should enhance brand image and provide animation and entertainment value to the brand. Like in the entertainment world, an effective flagship brand store stimulates physical and emotional sensations, which persuade the customer to stay longer and return to the store. 
Furthermore, flagship store success depends on the firm's ability to integrate interdisciplinary issues and commercial and artistic-creative communication.

\section{Originality of the Study}

The literature on flagship brand stores is growing; but in different directions. One is internationalization. Some scholars studied flagship stores as an entry method into a new market (Moore \& Doherty, 2007; Moore et al., 2010; Nobbs, Moore \& Sheridan, 2012; Van Marrewijk \& Broos, 2012; Manlow \& Nobbs, 2013; McGrath, Sherry \& Diamond, 2013). Some papers focused on luxury and fashion sectors analyzed flagship stores as international market entry model. Moore et al. (2010) was one of the first to introduce the flagship store on internationalization entry model debate. Foreign flagship brand stores (e.g. Apple), luxury brands (e.g. Cartier, Gucci, Armani) and other brands for example have been successful in China. Borghini et al. (2009) and McGrath et al. (2013) analyzed the case of failure of the House of Barbie Shanghai flagship store USA in China.

Furthermore, literature analyzed flagship stores as one example of post-modern experience and an entertainment economy. Kotler (1973) was the first to study the role of retail atmosphere as marketing tool. The United States was the first country to move from service economy toward an experience and entertainment economy. Furthermore, new segments of consumers shop to engage in fantasies, feelings, fun and pleasure, so flagship stores can be seen as an example of hedonistic consumption (Holbrook \& Hirschman, 1982; Pine \& Gilmore, 1999). Studies consider store design, signs, symbols, ambient condition, noise, music and aromas to have an impact on customers and employees (Bitner, 1992; Sherry, 1998; Sherry et al., 2001; Rosenbaum, 2005). One of the main objectives of flagship brand stores is to create a memorable and attractive shopping experience (Pine \& Gilmore, 1999; Kozinets et al., 2002).

Marketing literature has not paid due attention to semiotic interpretation of flagship brand stores. The increasing importance of intangible attributes has pushed the brand to a new communicative use of stores. For Semprini (2003), the brand evokes a possible world and tells stories, as if it was a work of literature, theatre, film. Louis Vuitton, e.g., is a brand that has managed to propose a possible world, starting from the imaginary of the trip, the quality of craftsmanship, as well as innovation (Semprini, 2003). The possible worlds evoked by the brand are the result of an even balance between fiction, fantasy, and possibility of identification and projection. Particularly in the luxury fashion sector, the idea that outlets' selling different brands was less able to support a strong brand image started to gain currency. The increasing importance given to non-tangible aspects of brand underpinned a surge of interest in single brand outlets.

The marketing approach and traditional media have lost credibility in the process of construction of the world of the brand. New flagship brand stores, on the other hand, are a container for the value system carried by the brand whereby the consumer can experience the brand in direct contact through several senses by visiting the "possible world". Flagship brand stores have become the incarnation of brand image, and they are taken over by the "world of the brand", and become a concrete symbol.

Only a few papers have studied flagship stores from the perspective of brand management (Doyle, Moore , Doherty \& Hamilton, 2008) and analyzed the role of store design in positioning a brand (Doyle \& Broadbridge, 1999). For these reasons, our work aims to study the evolution of the marketing roles of flagship stores in order to identify the main types of flagship stores.

The trend for innovative firms to integrate downstream with the designer stores is not a novelty. In the fashion sector, time-based competition, the shortening of the design-production-distribution cycle, and the faster pace of innovation all give advantage to vertically integrated firms. The concentration and increase of retail power involves the risk of increasing mismatch between advertising content from the manufacturer and the retailer. A new logic of vertical co-marketing is thus leading to downstream integration in the search for new forms of synergy between brand communication by the firm and advertising of, and in, sales outlets.

Moreover, as the consumer today is the target of excessive amounts of information, which have the effect of making orientation more difficult, a search for new filters and avenues can reassure him or her that choices are valid. Technological and production progress, the increase in product lines, and de-materialization has lowered the credibility of the branded product when it is out of context of a sales environment. It is increasingly difficult for the consumer to evaluate branded goods, so the sales outlet has become a new vector of qualification of the intangible aspects of the brand. Consumers today use location, additional services, sales people, store design, client profile and prestige of the store architect as a proxy for the value of the brand.

Brands on today's market need to find the best way of being a vehicle for their underlying values. They need to open new sales points and try out new instruments; they need to grasp new opportunities. A sales point supplies a 
higher number of such opportunities for contact with the consumer. Even in countries they are entering for the first time, a stand-alone brand outlet is particularly suitable for a brand that wants to make a statement and reach premium positioning rapidly.

The flagship store is a real and physical incarnation of the brand, as well as being long lasting. Therefore, it needs to give a flawless performance in expressing brand message; if the execution is not perfect it can harm the brand image. It needs to create a show and background to stage clothes; surprising the store visitor means he or she can play with the brand, try out the place, make discoveries and enjoy the experience. This has important implications for the architecture and animation of the flagship store. Raising its profile and showing its ability to exist beyond the actual goods by means of a flagship store, a brand can take off to become a whole approach to life, a culture or a spirit.

Flagship stores use location, employee, symbols, colors, music, and scents to communicate the brands character. The main goal of a flagship store is to create a multisensory experience representing the lifestyle of the brand. Now brands use different communication channels, and one is a flagship brand store. This strategy requires new skills, not only the typical skills of retail business and the skills of entertainment business (Kozinets et al., 2002).

Now the web 2.0 era is having a large impact on the retail sector and it is only the beginning of a new business revolution: the consumer decision-making process is radically evolving as the Internet can offer more information services than physical retail, at no charge. Furthermore, the rapid evolution of buzz marketing, social media marketing makes it easier to find information produced directly by customers.

\section{Research Limits}

While our research has valuable contributions, it also has some limitations. Limitations are associated with the qualitative methodology through which we conducted the research. Our study, however, wants to be a useful investigation about the evolution of the marketing roles of flagship stores. It is just a first step, which has opened considerable opportunity for our ongoing research to identify the main types of flagship stores within the retail environment.

\section{References}

Bitner, M. J. (1992). Servicescape: The impact of physical surroundings on customers and employees. Journal of Marketing, 56(2), 57-71. https://doi.org/10.1177/002224299205600205

Borghini, S., Diamond, N., Kozinets, R. V., Mcgrath, M. A., Muniz Jr, A. M., \& Sherry, Jr. J. F. (2009). Why are themed brandstores so powerful? Retail brand ideology at American Girl Place. Journal of Retailing, 85(3), 363-375. https://doi.org/10.1016/j.jretai.2009.05.003

Doyle, S. A., \& Broadbridge, A. (1999). Differentiation by design: the importance of design in retailer repositioning and differentiation. International Journal of Retail \& Distribution Management, 27(2), 72-83. https://doi.org/10.1108/09590559910258571

Doyle, S. A., Moore, C. M., Doherty, A. M. \& Hamilton, M. (2008). Brand context and control: the role of the flagship store in B\&B Italia. International Journal of Retail \& Distribution Management, 36(7), 551-563. https://doi.org/10.1108/09590550810880589

Holbrook, M. B., \& Hirschman, E. C. (1982). The experiential aspects of consumption: Consumer fantasies, feelings, and fun. Journal of Consumer Research, 9(2), 132-140. https://doi.org/10.1086/208906

Kent, T., \& Brown, R. (2009). Flagship marketing. New York: Routledge.

Kotler, P. (1973). Atmospherics as a marketing tool. Journal of retailing, 49(4), 48-64.

Kozinets, R. V., Sherry, J. F., Deberry-Spence, B., Duhachek, A., Nuttavuthisit, K., \& Storm, D. (2002). Themed flagship brand stores in the new millennium: theory, practice, prospects. Journal of retailing, 78(1), 17-29. https://doi.org/10.1016/S0022-4359(01)00063-X

Manlow, V., \& Nobbs, K. (2013). Form and function of luxury flagships: An international exploratory study of the meaning of the flagship store for managers and customers. Journal of Fashion Marketing and Management: An International Journal, 17(1), 49-64. https://doi.org/10.1108/13612021311305137

Mcgrath, M. A., Sherry, Jr. J. F., \& Diamond, N. (2013). Discordant retail brand ideology in the House of Barbie. Qualitative Market Research: An International Journal, 16(1), 12-37. https://doi.org/10.1108/13522751311289749

Moore, C. M., \& Doherty, A. M. (2007). The international flagship stores of luxury fashion retailers. Fashion Marketing, 277. 
Moore, C. M., Doherty, A. M., \& Doyle, S. A. (2010). Flagship stores as a market entry method: the perspective of luxury fashion retailing. European Journal of Marketing, 44(1/2), 139-161. https://doi.org/10.1108/03090561011008646

Nobbs, K., Moore C. M., \& Sheridan, M. (2012). The flagship format within the luxury fashion market. International Journal of Retail \& Distribution Management, 40(12), 920-934. https://doi.org/10.1108/09590551211274928

Pine, B. J., \& Gilmore, J. H. (1999). The experience economy: work is theatre \& every business a stage. Harvard Business Press.

Rosenbaum, M. S. (2005). The symbolic servicescape: Your kind is welcomed here. Journal of Consumer Behaviour, 4(4), 257-267. https://doi.org/10.1002/cb.9

Semprini, A. (2003). Marche e mondi possibili: un approccio semiotico al marketing della marca. 1 FrancoAngeli.

Sherry, Jr. J. F. (1998). The soul of the company store: Nike Town Chicago and the emplaced brandscape. Servicescapes: The concept of place in contemporary markets, 109-146.

Sherry, Jr. J. F., Kozinets, R. V., Storm, D., Duhachek, A., Nuttavuthisit, K., \& Deberry-Spence, B. (2001). Being in the zone: Staging retail theater at ESPN Zone Chicago. Journal of Contemporary Ethnography, 30(4), 465-510. https://doi.org/10.1177/089124101030004005

Van Marrewijk, A., \& Broos, M. (2012). Retail stores as brands: performances, theatre and space. Consumption, Markets \& Culture, 15(4), 374-391. https://doi.org/10.1080/10253866.2012.659438

Webb, B. (2009). A classification approach to flagship stores. Flagship Marketing: Concepts and Places, Routledge. New York, NY, 20-31.

\section{Copyrights}

Copyright for this article is retained by the author(s), with first publication rights granted to the journal.

This is an open-access article distributed under the terms and conditions of the Creative Commons Attribution license (http://creativecommons.org/licenses/by/4.0/). 